\title{
ANALYSIS OF WOMEN FARMERS' INVOLVEMENT IN ORGANIC FARMING OF MAIZE IN OHAJI-EGBEMA LOCAL GOVERNMENT AREA OF IMO STATE
}

\author{
Okoroh, Juochi P. and Ejike R. D. \\ Department of Agricultural Economics, Extension and Rural Development, Imo State University \\ Owerri, Imo, Nigeria. \\ Email:okorohjuochi@yahoo.com
}

\begin{abstract}
The study analysed women farmers' involvement in organic farming of maize in Ohaji-egbema, local government area of Imo state, Nigeria. It specifically described the socio-economic characteristics of women organic maize farmers, identified the organic practices engaged by women maize farmers, ascertained women farmers' level of involvement in organic farming of maize and identified the constraints militating against organic production of maize among farmers in the study area. Data for the study were collected from 80 women organic farmers through a multistage sampling procedure using structured questionnaire. Descriptive statistics and regression analysis were used for the analysis of the data generated. Results revealed that the majority (98.75\%) had formal education with a mean age of 55 years. Investigation on the organic practices showed that women in organic maize farming practiced more of intercropping (98.8\%), shifting cultivation (85\%) as well as animal manure (54\%). Result on the level of involvement showed that $52.5 \%$ of the farmers were moderately (6-10 organic practices) involved in organic farming. Lack of certification and distinction between organic and inorganic products in the market (82.5\%) were the major constraints. farming experience, income, educational level and household size were significant and positively related to women involvement in organic farming at 5\% level of significance. It was concluded that women are moderately involved in organic farming of maize in the study area. The study therefore recommends that there should be promotion for distinction of organic products in the market. Also the study recommends that the federal Government should enact a policy that will promote organic farming and their certification.
\end{abstract}

Key words: Organic farming, maize farmers, involvement.

https://dx.doi.org/10.4314/jafs.v17i2.13

\section{INTRODUCTION}

Maize is a staple food crop whose consumption is widespread across the country and among households. Maize is prepared as pap, flakes, cooked, roasted, fried, ground, pounded or crushed form (Abdulrahaman and Kolawole, 2006). In many parts of Nigeria, continuous cropping and use of inappropriate farming practices have had massive negative environmental impacts. These negative impacts are characterized by declining soil fertility, soil erosion and degradation of vast expanses of arable land thus, further causing low yields and food insecurity. For instance, Journal of the Faculty of Agriculture and Veterinary Medicine, Imo State University Owerri website: www ajol.info 


\section{Volume 17 Number 2, October 2019 pp 164 - 176}

practices like unguided application of agrochemicals, bush burning, deforestation, etc result in soil degradation (Asadu et. al., 2004; Amusa et. al., 2015). Over the years there has been emphasis on environmental degradation as a result of certain practices use by farmers such as bush burning, application of fertilizer, pesticides, herbicides etc. These are used by farmers in order to boost production but farmers failed to understand that these practices also have adverse effect on the environment and the future generation. According to Intergovernmental Panel on Climate Change (IPCC) (2007), opined that agriculture accounts for roughly 14\% of global greenhouse gases. Also a large amount of Nitrous Oxide emission has been attributed to fertilizer application (Rosenwig and Hillel, 1995). Researchers have been able to view the use of these chemicals beyond just providing the immediate need of boosting production rather the emphasis has shifted to sustainability. In order to sustain the environment to continue providing food for the future generation, there is need to encourage the farmers on the practice of organic farming which is environmentally and health friendly.

According to Mgbenka, Onwubuya and Ezeano (2015) organic farming is a form of agriculture that excludes the use of synthetic fertilizers and pesticides, plant growth regulator and livestock feed additives. International Federation of Organic Agriculture Movement (IFOAM) (2006) defines organic farming as the process of producing food naturally. It is based on minimal use of off-farm inputs a management practices that restore, maintain and enhance ecological harmony.

Organic systems rely on crop rotation, crop residues, animal manures, legumes, green manures, off-farm organic wastes and aspects of biological pest control to maintain soil productivity and tilt, to supply plant nutrient and to control insects, weed and other pests (Lampkin, 1990; Miguel, 1998). Most of the synthetic fertilisers and other agrochemicals that are used in non-organic farming are manufactured using resources such as fossil fuels which are not renewable. Using such resources may cause pollution and contribute to environmental degradation, thus making such agricultural practices unsustainable. Some inorganic fertilisers used to increase crop yield are leached or washed away by erosion to nearby rivers, causing water pollution, which is dangerous to aquatic life and human health (Smil 2001). In sub-Saharan Africa, poor soil fertility is one of the major causes of low agricultural productivity (Bationo and Mokwunye1991; Williams, 1999). Research indicates that organic manure increases yields of food crops and forages. It augments soil organic matter content, raises soil $\mathrm{pH}$, and improves nutrient exchange and water holding capacity of soil (Bationo et al., 1999).

However, despite these beneficial effects and the vital role in supporting crop production and soil fertility improvement, organic manure is not regularly applied by most farmers, even in areas where aggregate livestock population may permit its use (Adejobi and Kormawa, 2002) in SubSaharan Africa. The major goal of organic farming activities is a sustainable production of quality food with little or no effect on the environment. The goal of organic farming has not been fully achieved by the current agricultural practices, i.e. conventional farming hence, the need to encourage organic farming which is capable of providing solutions to the current agricultural problems and help to achieve optimal production of quality food sustainably (IFOAM, 2005).

Journal of the Faculty of Agriculture and Veterinary Medicine, Imo State University Owerri website: www ajol.info 
According to Oyetoro and Okunade (2001), women contribute up to 60-80\% agricultural labor in Nigeria and produce two-third of the crops eaten in Nigeria. Women in Imo State are involved in organic farming mostly those in the rural area, and they are engaged in one form of organic practices or the other like use of animal manure, green manure, organic waste, cover cropping, application of compost, legumes and mulching (Nnenna and Ugwumba, 2014). It therefore becomes necessary to analyze the extent to which women farmers are involved in organic farming and probably ascertain the constraints associated with organic farming in Ohaji-egbema. Owing to their high involvement in agriculture, is the situation the same in organic farming? This study therefore seeks to answer the following questions: What are the socio-economic characteristics of women farmers who engage in organic farming of maize in the study area? What are the organic practices women farmers in the study area engage in? What are the levels of women involvement in organic farming of maize in the study area? What are the constraints militating against organic farming of maize among women farmers in the study area?

The study analyzed women farmers' involvement in organic farming of maize in Ohaji-Egbema Local Government Area of Imo State. It specifically, described the socio-economic characteristics of women farmers engaged in organic farming of maize in Ohaji-Egbema LGA, identified the organic practices engaged by women maize farmers in Ohaji-Egbema LGA, ascertained women farmers' level of involvement in organic farming of maize and identified the constraints militating against organic production of maize among farmers in Ohaji-Egbema LGA.

\section{Hypothesis of the study}

$\mathbf{H}_{\mathbf{0}}$ : The socio-economic characteristics of the respondents do not influence the women farmers' level of involvement in organic farming of maize in Ohaji-EgbemaLGA.

\section{MATERIALS AND METHOD}

The first stage involved purposive selection of Ohaji-Egbema Local Government Area of Imo State because of the prevalent Practices of Organic farming among farmers in the area. The second stage involved random selection of 8 communities out of the 21 communities in OhajiEgbema Local Government Area. The third stage involved random selection of 10 maize farmers from each of the 8 selected communities giving a total sample size of 80 maize women farmers. Data collected for this study was through structured questionnaire and analysed using descriptive statistics such as mean, percentage and frequencies. Objectives i, ii \& iv were realized using descriptive statistics. Objective 3 was designed in a 3 point Likert-type scale of low, moderate and high level of involvement to elicit information and realized using frequency and percentage. To ascertain farmers level of involvement on organic production of maize, 15 indicators/indices perceived as organic practices were listed, namely; crop rotation, crop residues, mixed cropping, animal manure, green manure, organic waste, cover cropping, application of compost, legumes, mulching and mechanical cultivation, biological pest control, shifting cultivation, natural weeds and erosion control measures (Nenna and Ugwumba, 2014).

Journal of the Faculty of Agriculture and Veterinary Medicine, Imo State University Owerri website: www ajol.info 
The respondents were asked to tick either "Yes" or "No" out of the 15 indicators of organic farming. The respondents were asked to tick "Yes" or "No" to the organic practices they indulge in. One mark was awarded to "Yes" responses and zero to "No" responses. Each of the respondents was marked and scored over 15 ie, the total number of indicators of organic farming. Later the respondents were categorized into a 3-point Likert type scale of low, moderately and high level of involvement 0-5, 6-10, and 11-15 scores respectively.

The hypothesis for the study was tested using ordinary least square regression analysis.

The implicit model was given as follows;

$Y=f\left(X_{1}, X_{2}, X_{3}, X_{4}, X_{5}, X_{6}, X_{7}, X_{8}\right.$ ei $)$

$\mathrm{Y}=$ Level of involvement (Total scores for organic practices involved)

$\mathrm{X}_{\mathrm{I}}=$ Age (Years)

$\mathrm{X}_{2}=$ Marital Status (Dummy, 0 single and otherwise 1)

$\mathrm{X}_{3}=$ Farm Experience (years)

$\mathrm{X}_{4}=$ Level of Education (years spent in school)

$\mathrm{X}_{5}=$ Household Size (number)

$\mathrm{x}_{6}=$ Income (in naira)

$\mathrm{X}_{7}=$ number of organizational membership (actual number)

$\mathrm{E}=$ error term

\section{RESULTS AND DISCUSSION}

The mean age was 55 years. This agrees with the findings of Solomon (2008) that the mean age of organic farmers was 55 years, meaning that the farmers involved in organic farming activities are still at their productive age. This implies that greater proportion $(97.00 \%)$ of the farmers were married and approximately (2.50) \% were single. This implies that majority of the women farmers who engage in organic maize production in Ohaji-Egbema are married. This implies that married farmers will have access to production variables such as farmland and labour to practice their organic farming. The finding is in line with the study of Nnenna and Ugwumba (2014), who asserted that organic farming activities in South East Nigeria of which Imo state is included, is dominated by married individuals. The mean household size was approximately 6 persons. The implication of the finding is that farmers in Ohaji-Egbema have sizeable household size which is expected to lower cost of hiring labourers, this result also shares view with the studies of Agwu et al., (2008), that asserted that large household size is a proxy for labour and reduce the cost of hired labour. The mean farm size was 1.1 ha. This implies that the farmers in the study area are mainly small holder's farmers operating at subsistence level. This could be as a result of land tenure system predominant in the area or due to the increasing population. The mean annual income was $\$ 19,136$. This is as a result of small scale nature of their production. Journal of the Faculty of Agriculture and Veterinary Medicine, Imo State University Owerri website: www ajol.info 
Majority (70\%), of organic farmers belonged to one form of social group. This implies that organizational membership helps farmers share information together as opined by Onubuogu et al. (2014).

The result in Table 2, identified intercropping (98.8\%), shifting cultivation (85.5\%) and mixed cropping $(80.0 \%)$, as the major organic practices engaged by women maize farmers. Among, animal manure (71.3\%), mulching (62.5\%), green manure (57.5\%), natural wed control $(55.0 \%)$, compost and crop residue (53.8\%), domestic waste (51.3\%), cover cropping and legumes $(48.8 \%)$, erosion control $(45.0 \%)$, crop rotation (18\%) and biological pest control (0\%). This means that biological method of pest control is not prevalent in Ohaji-Egbema L.G.A. The result is in consonance with the findings of Nwachukwu (2010), who reported that farmers in Nigeria practice intercropping, shifting cultivation, mixed cropping among others with or without the knowledge and principles of organic agriculture.

\section{Level of women involvement in organic production of maize among maize farmers in Ohaji-Egbema}

The result of the Figure below shows that $55 \%$ of women organic maize farmers are moderately involved in organic production of maize (6-10 organic practices) in Ohaji-Egbema LGA.This implies that there are other organic practices that these women are not practicing in the area. This is in line with Sajal and Shimul (2015), which states that involvement of women in organic production had satisfactory moderate level.

\section{Constraints militating against organic production of maize in Ohaji-Egbema}

Table 3 shows that lack of certification and distinction between organic and inorganic products in the market $(82.5 \%)$ are major constraints among the constraints militating against women organic maize farmers in Ohaji-Egbema. Moses (2015) went further to say that organic farmers are not familiar with the requirements of certification process which among others require proper farm keeping for traceability.

Other constraints militating against organic production of maize in Ohaji-Egbema included; inadequate extension agents and high cost of labour (77.5\%), lack of institutional support $(73.8 \%)$, low yield $(68.8 \%)$, high price of organic products by government $(62.5 \%)$, lack of technical know-how (58.8\%), incidence of pests and diseases and poor local marketing (55.0\%). According to Mgbenka, Onwubuya and Ezeano (2015) who asserted that lack of certification is a constraint to organic farming in Nigeria.

\section{Hypothesis}

\section{Socio-economic factors that influence women farmer's involvement in organic farming of maize}

To test the hypothesis which states that the socio-economic characteristics of the respondents do not influence the women farmers' level of involvement in organic farming of maize in the study 
area, four functional forms of the multiple regression analysis (linear, semi-log, double log and Exponential forms) were tested. The linear functional form gave the best fit and was chosen as the lead equation. It had the highest number of significant variable with $\mathrm{R}^{2}$ value of 0.7360 and F-value of 24.768. The result of the linear form shows that the independent variables jointly explained $73.6 \%$ of the variations in women maize farmers' involvement in organic farming. Farming experience $\left(\mathrm{X}_{3}\right)$ was positive and significantly related to level of women involvement in organic farming of maize with a t- value of 2.186 at $5 \%$ probability level. This implies that the more the experience the more they want to get involved in organic production of maize

Educational level $\left(\mathrm{X}_{4}\right)$ was positive and significantly related to level of women farmers' involvement in organic farming of maize with a t-value of 3.524 at $5 \%$ probability level. This implies that education influences the level of women involvement in organic farming of maize. However, Eric et.al (2014) found that as the educational level increases, the level of women maize farmers' involvement in organic production also increases.

Household size $\left(\mathrm{X}_{5}\right)$ was positive and significantly related to level of women farmers' involvement in organic farming of maize with a t-value of 3.140 at $5 \%$ probability level. This implies that women organic maize farmers' that have large number of households are more likely to engage in organic farming of maize. This could be as a result of reduction in cost of hiring labour since large households tend to supply farm labour. This is in line with Agwu et al. (2008), who asserted that large household size is a proxy for labour and reduce the cost of hired labour.

Income $\left(\mathrm{X}_{6}\right)$ was positive and significantly related to women farmers' involvement in organic farming of maize with a t-value of 2.052 at $5 \%$ probability level. This implies that increase in the annual income leads to a significant increase in the level of women involvement in organic farming of maize in Ohaji-Egbema. Higher income households are more likely to engage in organic production, perhaps, households with more income will have the financial resources to purchase productive resources like land etc, and expand their scope of production.

\section{CONCLUSION AND RECOMMENDATION}

It was concluded that farmers in Ohaji-Egbema are moderately involved in organic farming of maize and the major constrained faced by these famers are non -certification of their produce and lack of distinction between organic and inorganic products in the market $(82.5 \%)$. The study therefore recommends that there should be promotion for distinction of organic products in the market. Also the study recommends that the Federal Government should enact a policy that will promote organic farming and their certification. 


\section{REFERENCES}

Abdurahaman, A. A. and Kolawole, O.M. (2006). Traditional preparations and uses of maize in Nigeria. Ethnobotanical leaflets International Journal of Agricultural Innovations and Research 10:219-227 http//www.eth

Agwu, A. E., Ekwueme, J. N \&Anyanwu A.C (2008). Adoption of improved agricultural disseminated via radio farmers programme by farmers in Enugu state Nigeria. Journal of Biotechnology, 7 (9): 1277-1286.

Asadu, C.C., Ezeaku, P.I. and Nnaji, G.U., (2004). Land use and soil Management situation in Nigeria. An analytical review of changes: Outlook Agriculture, 33:27-37

Bationo, A. and Mokwunye, A.U (1991). Role of Manures and Crop Residues in alleviating Soil Fertility Constraints to crop production with special reference to the Sahelian and Sudanian Zones of West Africa. World Journal of Agricultural Sciences 11(6):125-177.

Eric, O. O., Abogaye, A. P. \&Acquaye, N. A. (2014). Effects of education on the agricultural productivity of farmers in the Offinso municipality. International journal of development Research, 4(9):1951-1960, Sept. 2014.

Intergovernmental Panel on Climate Change (IPPC), (2007). Impacts, Adaptation and Vulnerability contribution of working group II to the fourth Assessment Report of the IPCC [Parry, M. L., Canziani, O.F., Paul J. and Hanson, C. E. (eds.)] Cambridge University Press, United Kingdom.

International Federation of Organic Agriculture Movement, [IFOAM] (2006); Basic standards for organic production and processing. Thorley, Germany.

Mgbenka, R.N., Onwubuya, E.A. and Ezeano, C. I. (2015). Organic farming in Nigeria. Need for population and policy. World Journal of Agricultural Sciences 11(6): 346-355, 2015.

Moses, K. N., (2015). Challenges and benefits of organic farming among farmers in NembureDivision, Embu County Kenya. International Journal of Humanities and Social Science, 5(12):

Nnenna, M.G. and Ugwumba, C.O (2014). Utilization of organic farming Technologies among small scale farmers. International Journal ofAgricultural Innovations and Research

Nwachukwu, C.A. (2010) Adoption of Organic Agricultural Technologies: Implication for Radio Farmer Agricultural Extension Programme in Imo State, Nigeria. Scientific and Technical Information and Rural Development. $11^{\text {th }}$ World congress, Montepellier, 26-29 April, 2010.

Onubuogu, G. C.; Esiobu, N. S.; Nwosu, C. S. and Okereke, C. N. (2014). Resource use efficiency of smallholder cassava farmers in Owerri agricultural zone, IMO state, Nigeria: Scholarly Journal of Agricultural Science, 7(8): 142-152.

Journal of the Faculty of Agriculture and Veterinary Medicine, Imo State University Owerri website: www ajol.info 
Oyetoro, A. O., Adesala, S.O. and Kuyoro, A. A. (2001) Development of "KoKoro" with Maize Soya and Maize Groundnut blends. Proceedings of $31^{\text {st }}$ Annual Conference and General meeting of Nigerian Institute of Food Science and Technology ,21-24 April, 2001.

Lampkin, N. (1994). Farm level performance of organic farming systems in Lampkin, W., Pandel, S (eds). The economics of organic farming an International review.

Rosenzwig, C. and Hillel D. (1995). Potential impacts of climate change on Agriculture and food supply consequences. Journal of Agriculture and Environment, 1(2): 133-138.

Sajal, A.O. and Shimul, D.O. (2015) Women involvement in Organic Farming. Research Gate. Western Sydney University Volume 5 Number 96.

Solomon, O. (2008). Small scale oil palm farmers' perception of organic agriculture in Imo state, Nigeria, Journal of Environmental Extension, 7:67-71. 
APPENDIXES

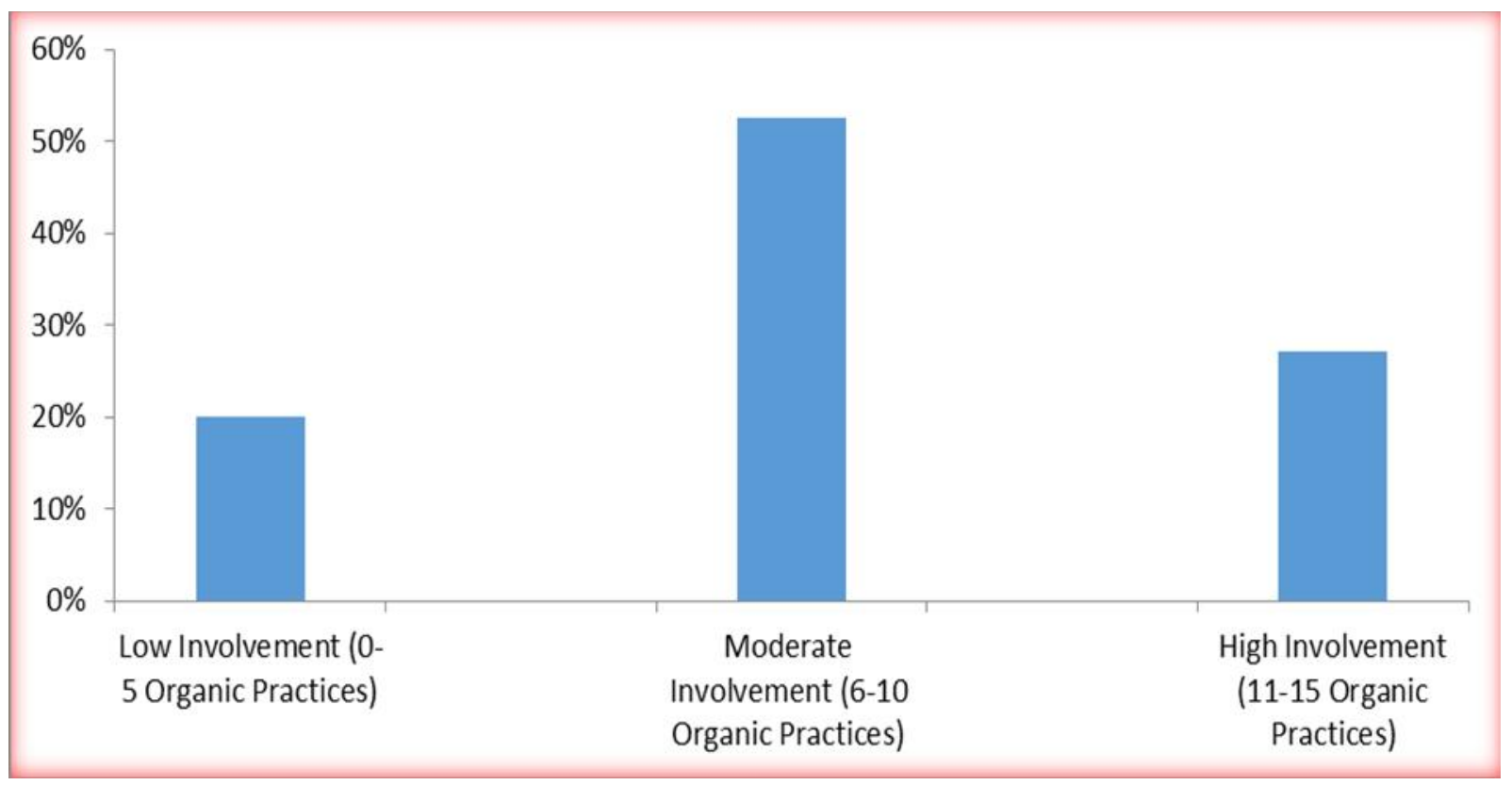

Figure 1: Level of women involvement in organic production of maize

Field survey data, 2018

Journal of the Faculty of Agriculture and Veterinary Medicine, Imo State University Owerri website: www ajol.info 
Journal of Agriculture and Food Sciences

Volume 17 Number 2, October 2019 pp $164-1.76$

Okoroh, J. P. and Ejike R.D.

Table 1: Socio-economic characteristics of women organic maize farmers

\begin{tabular}{|c|c|c|c|}
\hline Socio-economic variables & Frequency & Percentage $\%$ & Mean \\
\hline \multicolumn{4}{|l|}{ Age(years) } \\
\hline $30-39$ & 9 & 11.25 & \\
\hline $40-59$ & 18 & 22.50 & 55 \\
\hline $50-69$ & 44 & 55.00 & \\
\hline $70-79$ & 9 & 11.25 & \\
\hline \multicolumn{4}{|l|}{ Marital status } \\
\hline Married & 78 & 97.5 & \\
\hline Single & 2 & 2.5 & \\
\hline \multicolumn{4}{|l|}{ Educational Level } \\
\hline Non-formal education & 1 & 1.25 & \\
\hline Primary education & 41 & 51.25 & \\
\hline Secondary education & 27 & 33.75 & \\
\hline Tertiary education & 11 & 13.75 & \\
\hline \multicolumn{4}{|l|}{ Farming Experience } \\
\hline $1-10$ & 15 & 18.75 & \\
\hline $11-20$ & 19 & 23.75 & \\
\hline $21-30$ & 13 & 16.25 & \\
\hline $31-40$ & 17 & 21.25 & \\
\hline $41-50$ & 12 & 15 & \\
\hline \multicolumn{4}{|l|}{ Household size } \\
\hline $1-5$ & 39 & 48.75 & \\
\hline $6-10$ & 41 & 51.25 & \\
\hline \multicolumn{4}{|l|}{ Annual Income } \\
\hline $1000-20000$ & 60 & 75 & \\
\hline $21000-40000$ & 9 & 11.25 & \\
\hline $41000-60000$ & 9 & 11.25 & 19,136 \\
\hline $61000-80000$ & 2 & 2.5 & \\
\hline \multicolumn{4}{|l|}{ Farm size } \\
\hline $0.1-20$ & 72 & 90 & \\
\hline $2.1-40$ & 6 & 7.5 & 1.1 \\
\hline $4.1-6.0$ & 1 & 1.25 & \\
\hline $6.1-8.0$ & 1 & 1.25 & \\
\hline \multicolumn{4}{|l|}{ Organizational membership } \\
\hline Member & 56 & 70 & \\
\hline Non-member & 24 & 30 & \\
\hline
\end{tabular}

Journal of the Faculty of Agriculture and Veterinary Medicine, Imo State University Owerri website: www ajol.info 
Volume 17 Number 2, October 2019 pp $164-176$

Different Organic Practices engaged by women organic maize famers in Ohaji-Egbema L.G.A

\begin{tabular}{llll}
\hline Organic practices & Frequency & Percentage & Rank \\
\hline Intercropping & 79 & 98.8 & $1^{\text {st }}$ \\
Shifting cultivation & 68 & 85.0 & $2^{\text {nd }}$ \\
Mixed cropping & 64 & 80.0 & $3^{\text {rd }}$ \\
Animal manure & 57 & 71.3 & $4^{\text {th }}$ \\
Mulching & 50 & 62.5 & $5^{\text {th }}$ \\
Green manure & 46 & 57.5 & $6^{\text {th }}$ \\
Natural weed & 44 & 55.0 & $7^{\text {th }}$ \\
Crop residue & 43 & 53.8 & $8^{\text {th }}$ \\
Compost & 43 & 53.8 & $8^{\text {th }}$ \\
Domestic waste & 41 & 51.3 & $10^{\text {th }}$ \\
Legumes & 39 & 48.0 & $11^{\text {th }}$ \\
Cover cropping & 39 & 48.0 & $11^{\text {th }}$ \\
Erosion control & 36 & 45.0 & $13^{\text {th }}$ \\
Crop rotation & 15 & 18.0 & $14^{\text {th }}$ \\
Biological pest control & 0 & 0 & $15^{\text {th }}$ \\
\hline
\end{tabular}

Multiple responses were recorded; Source: Field survey Data, 2018.

Journal of the Faculty of Agriculture and Veterinary Medicine, Imo State University Owerri website: $w w w$ ajol.info 
Journal of Agriculture and Food Sciences

Okoroh, J.P. and Ejike R.D.

Volume 17 Number 2, October 2019 pp 164 - 176

Table 3: Distribution according to constraints to women involvement in organic maize farming in Ohaji-Egbema, local Government Area

\begin{tabular}{llll}
\hline Constraints & Frequency & Percentage & Rank \\
\hline Lack of certification & 78 & 82.5 & $1^{\text {st }}$ \\
Distinction between organic and inorganic products & 78 & 82.5 & $1^{\text {st }}$ \\
High cost of labour & 62 & 77.5 & $3^{\text {rd }}$ \\
Inadequate extension agents & 62 & 77.5 & $3^{\text {rd }}$ \\
Lack of institutional support & 57 & 73.8 & $5^{\text {th }}$ \\
Low yield & 55 & 68.8 & $6^{\text {th }}$ \\
High price of organic manure & 50 & 62.5 & $7^{\text {th }}$ \\
Non promotion of organic products by government & 50 & 62.5 & $7^{\text {th }}$ \\
Incidence of pests and diseases & 44 & 55.0 & $9^{\text {th }}$ \\
Poor local marketing & 44 & 55.0 & $9^{\text {th }}$ \\
\hline
\end{tabular}

Multiple responses were recorded; Source: Field survey data, 2018

Journal of the Faculty of Agriculture and Veterinary Medicine, Imo State University Owerri website: www ajol.info 
Volume 17 Number 2, October 2019 pp 164 - 176

Table 4: Regression estimate of Socio-economic factors that influence women farmer's involvement in organic farming of maize

\begin{tabular}{|c|c|c|c|c|}
\hline Explanatory variable & Linear \pm & Semi-log & Double-log & Exponential \\
\hline \multirow[t]{2}{*}{ Constant } & 4.688 & -11.446 & -0.670 & 1.570 \\
\hline & $(3.667)^{* * *}$ & $(-2.811)^{* *}$ & $(-1.160)$ & $(8.739)^{* * *}$ \\
\hline \multirow[t]{2}{*}{ Age $\left(X_{1}\right)$} & -0.025 & -0.937 & -0.126 & -0.003 \\
\hline & $(-1.604)$ & $(-1.400)$ & $(-1.323)$ & $(-1.498)$ \\
\hline \multirow[t]{2}{*}{ Marital status $\left(\mathrm{X}_{2}\right)$} & -1.082 & -0.848 & -0.093 & -0.119 \\
\hline & $(-1.103)$ & $(-1.704)$ & $(-0.830)$ & $(-0.866)$ \\
\hline \multirow[t]{2}{*}{ Farm experience $\left(\mathrm{X}_{3}\right)$} & 0.031 & 0.324 & 0.055 & 0.005 \\
\hline & $(2.186)^{*}$ & $(1.239)$ & $(1.492)$ & $(2.280)^{*}$ \\
\hline \multirow[t]{2}{*}{ Education level $\left(\mathrm{X}_{4}\right)$} & 0.188 & 0.676 & 0.105 & 0.028 \\
\hline & $(3.524)^{* *}$ & $(2.119)^{*}$ & $(2.329)^{*}$ & $(3.681)^{* * *}$ \\
\hline \multirow[t]{2}{*}{ Household size $\left(\mathrm{X}_{5}\right)$} & 0.466 & 1.080 & 0.134 & 0.060 \\
\hline & $(3.140)^{* *}$ & $(1.649)$ & $(1.448)$ & $(2.886) * *$ \\
\hline \multirow[t]{2}{*}{ Income $\left(\mathrm{X}_{6}\right)$} & 4.397E-005 & 2.108 & 0.285 & 4.596E-006 \\
\hline & $(2.052)^{*}$ & $(5.006)^{* * *}$ & $(4.770)^{* * *}$ & (1526) \\
\hline \multirow[t]{2}{*}{ Organizational membership $\left(\mathrm{X}_{7}\right)$} & 0.316 & 0.187 & 0.022 & 0.038 \\
\hline & $(0.942)$ & $(0.689)$ & $(0.563)$ & $(0.799)$ \\
\hline $\mathrm{R}^{2}$ & 0.736 & 0.835 & 0.803 & 0.689 \\
\hline F-ratio & $24.768 * * *$ & $44.293 * * *$ & $35.584 * * *$ & $19.707 * * *$ \\
\hline
\end{tabular}

Source: Field Survey, 2018

Figures in parentheses are t-ratios.

*** Significant at 1\%; ** significant at $5 \%$ and $*$ significant at $10 \%$ 